\title{
Perineal Muscle Strength During Pregnancy and Postpartum: the Correlation Between Perineometry and Digital Vaginal Palpation ${ }^{1}$
}

\author{
Maria Luiza Gonzalez Riesco² \\ Adriana de Souza Caroci ${ }^{3}$ \\ Sonia Maria Junqueira Vasconcellos de Oliveira ${ }^{4}$ \\ Maria Helena Baena de Moraes Lopes ${ }^{5}$
}

Digital vaginal palpation performed during clinical practice can help diagnose urinary, intestinal and sexual disorders, while perineometry is more useful for performing perineal exercises with biofeedback. This study verifies whether there is a correlation between values of Pelvic Floor Muscle Strength (PFMS) obtained through perineometry performed with an electronic perineometer and through digital vaginal palpation using the Oxford scale. This is a prospective cohort study with 330 measurements carried out in 110 women. Data were collected from 2007 to 2008 in the health service system in Itapecerica da Serra, São Paulo, Brazil. Evaluations were carried out at three points in time: up to 12 weeks of pregnancy; between 36-40 weeks; and between 42-60 days postpartum. The Spearman coefficient indicated a strong positive correlation between the two evaluation methods for the three evaluations $(p<0.0001)$. The conclusion is that both methods are valid for measuring PFMS during pregnancy and after delivery.

Descriptors: Pelvic Floor; Electromyography; Perineum; Lacerations.

\footnotetext{
${ }^{1}$ Supported by Fundação de Apoio à Pesquisa do Estado de São Paulo, process \# 07/00357-5.

${ }^{2}$ Free Lecture, Associate Professor, Escola de Enfermagem, Universidade de São Paulo, SP, Brazil. E-mail: riesco@usp.br.

${ }^{3}$ Ph.D. in Nursing, Professor, Centro Universitário Adventista de São Paulo, SP, Brazil. E-mail: acarocic@hotmail.com.

${ }^{4}$ Free Lecture, Associate Professor, Escola de Enfermagem, Universidade de São Paulo, SP, Brazil. E-mail: soniaju@usp.br.

${ }^{5}$ Free Lecture, Associate Professor, Faculdade de Ciências Médicas, Universidade Estadual de Campinas, SP, Brazil. E-mail: mhbaenaml@yahoo.com.br.
}

Corresponding Author:

Maria Luiza Gonzalez Riesco

Universidade de São Paulo. Escola de Enfermagem.

Av. Dr. Enéas de Carvalho Aguiar, 419

Bairro Cerqueira César

CEP: 05403-000 São Paulo, SP, Brasil

E-mail: riesco@usp.br 


\title{
Avaliação da força muscular perineal durante a gestação e pós-parto: correlação entre perineometria e palpação digital vaginal
}

Na prática clínica, a palpação vaginal digital auxilia no diagnóstico de disfunções urinárias, intestinais e sexuais, enquanto a perineometria é mais utilizada para realizar exercícios perineais com biofeedback. O objetivo foi verificar se existe correlação entre os valores da força muscular perineal (FMP), avaliada pela perineometria, utilizando o perineômetro eletrônico, e por meio da palpação digital vaginal, utilizando a escala de Oxford. O estudo deriva de coorte prospectiva, com 330 mensurações, em 110 mulheres. A coleta de dados ocorreu em 2007 e 2008, em serviços de saúde de Itapecerica da Serra, São Paulo. A avaliação foi realizada em três momentos: até 12 semanas de gestação, entre 36-40 semanas, entre 42-60 dias pós-parto. O coeficiente de Spearman indicou forte correlação positiva entre os dois métodos de avaliação, nos três momentos $(p<0,0001)$. Conclui-se que ambos os métodos são válidos para mensurar a FMP durante a gravidez e após o parto.

Descritores: Soalho Pélvico; Eletromiografia; Períneo; Lacerações.

\section{Evaluación de la fuerza muscular perineal durante la gestación y posparto: correlación entre perineometría y palpación digital vaginal}

\begin{abstract}
En la práctica clínica, la palpación vaginal digital auxilia en el diagnóstico de disfunciones urinarias, intestinales y sexuales, en cuanto la perineometría es más utilizada para realizar ejercicios perineales con biofeedback. El objetivo fue verificar se existe correlación entre los valores de la Fuerza Muscular Perineal (FMP) evaluada por la perineometría utilizando el perineómetro electrónico, y por medio de la palpación digital vaginal, utilizando la escala de Oxford. El estudio deriva de una cohorte prospectiva, con 330 mensuraciones en 110 mujeres. La recolección de datos ocurrió en 2007 y 2008, en servicios de salud de Itapecerica de la Serra, en Sao Paulo. La evaluación fue realizada en tres momentos: hasta 12 semanas de gestación; entre 36 y 40 semanas; y, entre 42 y 60 días posparto. El coeficiente de Spearman indicó una fuerte correlación positiva entre los dos métodos de evaluación, en los tres momentos $(p<0,0001)$. Se concluye que ambos métodos son válidos para mensurar la FMP durante la gravidez y después del parto.
\end{abstract}

Descriptores: Suelo Pélvico; Electromiografía; Perineo; Laceraciones.

\section{Introduction}

Damage caused to a woman's pelvic floor (PF) can lead to diminished or the loss of Pelvic Floor Muscle Strength (PFMS) and consequently to genital prolapse, fecal and urinary incontinence and constipation. About one third of adult women have Urinary Incontinence ${ }^{(1-2)}$ (UI), which can impair a woman's physical, sexual, domestic, and professional and leisure activities ${ }^{(2-4)}$.

Pregnancy, vaginal delivery, parity, duration of the second stage of labor, difficulty in fetal extraction during a cesarean section, newborn's weight, perineal trauma and other mechanical, endocrinal and neural factors can lead to reduction or loss of the pelvic floor muscle tone causing genitourinary disorders ${ }^{(1-10)}$.
Altered PFMS has been the focus of studies and research due to the evolution of equipment and exams that make its evaluation and prognosis more precise ${ }^{(10)}$. To evaluate the PF muscles and diagnose disorders in the genitourinary and anal tracts, different exams are used: magnetic resonance, manometry, anal endosonography, translabial ultrasound, electromyography, perineometry, digital vaginal palpation, and neurophysiological and urodynamic studies of the $\mathrm{PF}^{(2,5-8,10-13)}$.

Perineometry and digital vaginal palpation are the most frequently used methods to measure PFMS in clinical practice(11-13). Evaluating PFMS can be essential in determining the type of treatment for women who present certain morbidities in the genitourinary tract ${ }^{(14)}$ 
Studies evaluating PFMS through digital vaginal palpation and perineometry revealed that even though these are different methods, they are positively

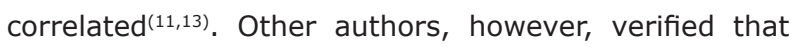
there is no significant correlation between digital vaginal palpation and perineometry ${ }^{(15)}$.

The following question was investigated in this study: Can digital vaginal palpation be used to evaluate PFMS as an alternative to perineometry?

Therefore, this study verifies whether there is correlation between the two methods, perineometry and digital vaginal palpation, in PFMS evaluation in pregnant and postpartum women.

\section{Method}

This is a prospective cohort study addressing the evaluation of PFMS through perineometry and vaginal digital palpation. The population was composed of pregnant women who attended antenatal care in five Primary Care Units (PCU) and whose deliveries were performed in two hospitals in Itapecerica da Serra, SP, Brazil. The inclusion criteria were: being primigesta with up to 12 weeks of pregnancy. Exclusion criteria were: multiple pregnancies; abdominal or previous urogenital surgery; hormonal therapy; diseases that can interfere in PFMS; refusal of the women to allow digital vaginal palpation or the insertion of a perineometer into the vagina; difficulty in understanding the Portuguese language or communication difficulties.

The parameter adopted to calculate the sample size of women in the cohort study was the difference between the average PFMS evaluated in postpartum women who had cesarean section and vaginal delivery with perineal laceration ${ }^{(12)}$. An alternative formula was used to determine the sample in order to compare two averages when the groups have different sizes $^{(16)}$.

A total of 136 pregnant women would be necessary to compose the cohort, assuming a probability of type one as being $5 \%$ and power of $80 \%$. Because it is a longitudinal study with the possibility of dropouts, the number of participants was increased $50 \%$, hence 204 women needed to be recruited. Aiming to ensure the maximum number in the estimated sample, 226 pregnant women were included in the study.

Data were collected between February 2007 and August 2008. The data collection form was exclusively developed for this study. The instrument and equipment used were previously tested and assistants were trained in the data collection technique.
Data collection was carried out at three points in time: at the beginning of the pregnancy (up to 12 weeks), at the end of pregnancy (36 to 40 weeks) and during puerperium (42 to 60 days postpartum).

Antenatal and puerperal consultations were carried out during data collection followed by the services' protocol. In the period of hospitalization for childbirth, one of the researchers visited the participants in the hospital and scheduled the return visit to the PCU to perform a postpartum evaluation. If any of the women missed the consultations, the researcher would visit them at home.

The study was approved by the Research Ethics Committee (604/2006/CEP-EEUSP). The participation of the women was voluntary and they signed free and informed consent forms. Researchers have no agreements with the manufacturers or distributors of the equipment used in this study.

\section{Methods used to measure PFMS}

All the participants underwent two methods of PFMS measurement: perineometric (electronic perineometer) and digital vaginal palpation (Oxford scale). A table to randomly apply the sequence of PFMS measurement methods was used through a statistical program aiming to avoid biased data. The sequence cards were put in opaque envelopes opened only at the moment of the PFMS measurements. Hence, perineometry or vaginal digital palpation could be either the first or last measurement performed.

\section{Perineometry}

The electronic pressure perineometer model Perina 996-2 ${ }^{\circledR}$ Quark was used. It registers the potential action of PF muscle contractions and translates their intensity to visual signs through a numerical scale graded from 0 to $46.4 \mathrm{mmHg}$. This device does not discriminate between pelvic floor and abdominal contractions. The chosen perineometer met all the requirements of the safety standard for electrometrical equipments and is registered in the Brazilian National Sanitary Surveillance Agency, Ministry of Health.

\section{Surface Electromyography}

To control abdominal relaxation during PFMS measurement, a surface electromyography model BioADS1200 ${ }^{\circledR}$ Lynx was used to detect, through external electrodes, electrical activity of the muscle during rest and contraction. It works with software linked 
to a computer; a graphic showing muscle activity appears in the screen. Records of PFMS indicated in the perineometer were only considered when the surface electromyography indicated abdominal muscle activity was compatible with rest (EMG scale between 0 and 10 microvolts).

\section{Digital Vaginal Palpation}

The Oxford Scale(17) was used to classify PFMS as follows: Grade 0 - no contraction; Grade 1 - hint of nonsustained small contraction; Grade 2 - low intensity but sustained contraction; Grade 3 - moderate contraction with increased intravaginal pressure, compressing the fingers and presenting small elevation of the vaginal wall; Grade 4 - satisfactory contraction, compressing the fingers of the examiner with elevation of the vaginal wall toward the pubic symphysis.

\section{Procedures for measuring PFMS}

1. Place the woman in the gynecological position with the genital region and inferior limbs naked and protected by a sheet; 2 . Connect the four electromyography electrodes to the rectus-abdominal muscles (two electrodes on the right side and two on the left side, between the top edge of the pubis and the umbilical region); 3 . Put on procedure gloves; 4 . Instruct the woman to make contractions as if "holding" urine using only the PF muscles and avoiding contracting abdomen, thigh and buttocks muscles.

\section{Perineometer}

1. Zero the scale pressure level; 2 . Cover the elastic tube with a disposable but non-lubricated condom; 3 . Lubricate the condom with lubricating gel; 4. Introduce the tube three to four centimeters in the vagina; 5 . Instruct the woman to relax the PF muscles; 6. Ask the woman to contract and keep the voluntary contraction of the pelvic floor muscles around the vaginal tube as long as possible in a sequence of three sessions with an interval of 15 seconds between each session; 7. Keep the vaginal tube in all PFMS measurements; 8 . Register the strongest voluntary contraction of the PF muscles; 9. Rest for one minute before initiating the digital vaginal palpation (in case it was not previously performed in a random fashion).

\section{Digital vaginal palpation}

1. Introduce the two distal phalanges of the index and middle fingers into the vagina with lubricating gel; 2. Ask the woman to contract and keep the voluntary contraction of the pelvic floor muscles around the examiner's finger as long as possible in a sequence of three sessions with an interval of 15 seconds between each session; 3. Keep the finger in the vagina during all PFMS measurements; 4 . Record the highest classification of contraction according to the Oxford scale; 5. Rest for one minute before beginning perineometry (in case it was not previously performed in a random fashion).

\section{Data treatment and analysis}

Data were entered twice in the Epi-info 6. The database was validated and imported into Excel.

Spearman's $\rho$ coefficient was computed in each of the measurements to verify whether there was correlation between the PFMS values obtained in the two measurement methods; probability of a type one error was considered at $5 \%$.

\section{Results}

A total of 116 women dropped out of the study among the 226 women that met the inclusion criteria. Due to the high number of women who decided not to continue the study, a comparative analysis was performed between the women included in the final sample and those excluded from the study, aiming to verify whether the losses were random and did not influence the sample result, especially in relation to PFMS. Hence, the final sample was composed of 110 women who completed all the cohort measurements. Considering that the measurements of PFMS were carried out at three different points of time, a total of 330 measurements were obtained.

The pregnant women's average age was $21.4 \pm 5.1$ years; $73.6 \%$ of the women reported being non-white; $44.5 \%$ had a paid job and $35.5 \%$ were housewives.

The PFMS values obtained through perineometry and digital vaginal palpation grouped according to Grades 0 to 2, 3 and 4 to 5 are presented in Table 1 . 
Table 1 - Average values of perineometry (in $\mathrm{mmHg}$ ) and digital vaginal palpation (Oxford scale grades) according to the point at which the evaluation was performed. Itapecerica da Serra, SP, Brazil. February 2007 to August 2008

\begin{tabular}{|c|c|c|c|c|c|c|}
\hline \multirow{3}{*}{ Digital Vaginal Palpation (grade) } & \multicolumn{6}{|c|}{ Perineometry $(\mathrm{mmHg})$} \\
\hline & \multicolumn{2}{|c|}{ Up to 12 weeks of pregnancy } & \multicolumn{2}{|c|}{$36-40$ weeks of pregnancy } & \multicolumn{2}{|c|}{$42-60$ post partum } \\
\hline & $\mathbf{n}$ & Average (SD) & $\mathbf{N}$ & Average (SD) & $\mathbf{n}$ & Average (SD) \\
\hline 0 to 2 & 34 & $6.2(7.3)$ & 56 & $6.8(12.3)$ & 56 & $10.2(8.3)$ \\
\hline 3 & 20 & $15.2(5.3)$ & 28 & $18.7(12.4)$ & 35 & $18.3(8.7)$ \\
\hline 4 to 5 & 56 & $22.0(9.8)$ & 26 & $29.6(12.6)$ & 19 & $28.3(9.4)$ \\
\hline
\end{tabular}

Table 2 presents the analysis of the correlation between the PFMS results evaluated by the two methods. This analysis was performed separately for each evaluation point in time, indicating a strong positive correlation between all them.

Table 2 - Correlation between the PFMS values obtained through perineometry (in $\mathrm{mmHg}$ ) and digital vaginal palpation (Oxford scale grades) $(n=110)$. Itapecerica da Serra, SP, Brazil. February 2007 to August 2008

\begin{tabular}{lcc}
\hline \multicolumn{1}{c}{ Perineometry $x$ palpation } & Spearman's $\boldsymbol{\rho}$ & p-value $<$ \\
\hline Up to 12 weeks of pregnancy & 0.771 & 0.0001 \\
Between 36-40 weeks of pregnancy & 0.814 & 0.0001 \\
Between 42-60 days postpartum & 0.703 & 0.0001 \\
\hline
\end{tabular}

$\rho>0.70$ (strong correlation); $\rho=0.30-0.70$ (moderate correlation); $\rho<$ 0-0.30 (poor correlation)

\section{Discussion}

The variables analyzed to compare the dropout group and the studied sample indicated homogeneity between groups, which reduces the probability of bias due to the loss of cohort follow-up.

The PFMS values obtained through perineometry can be classified according to intensity: absence of contraction (0.0); mild contraction ( 1.6 to $16.0 \mathrm{mmHg}$ ); moderate contraction (17.6 to $32.0 \mathrm{mmHg}$ ); normal contraction (33.6 to $46.4 \mathrm{mmHg})^{(11)}$. The results of the three points of evaluation revealed that when the digital vaginal palpation was between grades 0 and 2, perineometry indicated mild contraction and when the digital vaginal palpation indicated grades 3 to 5 , contraction was evaluated as moderate by perineometry.

The strong positive correlation obtained in this study between the two methods of evaluating PFMS indicates that perineometry can be validated by the clinical method of digital vaginal palpation using the Oxford scales, which is in agreement with other authors' conclusions(11,13).
This correlation is important because in the absence of a perineometer, a specialized professional can perform evaluation through digital vaginal palpation ${ }^{(13)}$.

On the other hand, no significant correlation was found in a study carried out with 20 women using these same methods to evaluate PFMS. The article held that appropriate measurement of PFMS depended on the cooperation and position of the participants as well as the previous experience of the researcher, which hinder the evaluation task ${ }^{(15)}$.

We must take into account that even with technical standardization, randomization of the sequence of application of methods, previous instruction to women and PFMS measurements performed by the same professional, there were cases in which the Oxford scale indicated grades incompatible with values inferred by the perineometer.

The women participating in this study showed positive acceptance of the PFMS evaluation with both methods considering that, even though these are painless procedures, they may cause embarrassment and discomfort. It is worth noting that the evaluation was performed in the context of a antenatal consultation and postpartum return visit, situations in which a good rapport has been established between the researchers and participants. Of the total of women included in the study, $1.8 \%$ refused to continue the study.

It is important to stress that further studies addressing PFMS measurement are necessary to establish a profile of PFMS during pregnancy and puerperium. It is also essential that the professional caring for these women value not only the identification of factors related to reduced PFMS but also encourage them to practice exercises to strengthen the PF muscles and also to report complains related the genitourinary

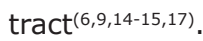

Evaluating PFMS in the postpartum may serve as reference for guiding and preventing permanent 
disorders or aggravation in the long term. Digital vaginal palpation is a simple method with no costs and does not require special equipment. However, it does require that the professional performing it to be appropriately trained to evaluate PFMS. This method has helped in the diagnosis of urinary, intestinal and sexual disorders. Performing perineometry is more important in the realization of pelvic floor exercises with biofeedback for treating these disorders ${ }^{(2-3,5,9-13,15)}$.

A relevant methodological aspect in this study was the use of surface electromyography during the PFMS evaluation because women showed difficulty in distinguishing contractions of the pelvic floor and abdominal muscles. The use of this equipment avoided registering PFMS performed simultaneously with abdominal muscle contractions ${ }^{(18)}$.

Another important aspect of how data were collected to stress is that one researcher measured PFMS while another read the perineometry result. This sought to avoid the result of perineometry influencing the researcher while performing the digital vaginal palpation.

Several devices and evaluation methods and also a lack of standardized parameters to classify the pelvic floor function are observed in the literature, which limit comparison of results of different studies. Hence, this is a topic that warrants further investigation and debate.

In addition to issues related to PFMS evaluation, scientific literature also analyzes the impact of UI on women's emotional health - suffering, diminished selfesteem, isolation, difficulties coping with the problem, among others - which provides an important contribution to nursing practice in women's health(19).

\section{Conclusion}

This study's results indicate that there is a positive correlation between the PFMS values obtained through perineometry and digital vaginal palpation, which indicates that both methods are valid measures of PFMS.

\section{Acknowledgments}

We thank the state of São Paulo Research Foundation, FAPESP, for the financial support provided to this study, the University of São Paulo, College of Nursing, and the Adventist University Center for institutional support.

\section{References}

1. Glazener CMA, Cooper K. Anterior vaginal repair for urinary incontinence in women (Cochrane Review). In: The Cochrane Library, Issue 3, 2003. Oxford: Update; 2003.

2. Voorham-van der Zalm PJ, Lycklama à Nijeholt GAB, Elzevier $\mathrm{HW}$, Putter $\mathrm{H}$, Pelger RCM. Diagnostic investigation of the pelvic floor: a helpful tool in the approach in patients with complaints of micturition, defecation, and/or sexual dysfunction. J Sex Med 2008 April; 5(4):864-71.

3. Norton C, Hosker G, Brazzelli M. Biofeedback and/or sphincter exercises for the treatment of faecal incontinence in adults (Cochrane Review). In: The Cochrane Library, Issue 3, 2003. Oxford: Update; 2003.

4. Brubaker L, Handa VL, Bradley CS, Connolly A, Moalli P, Brow $M B$, et al. Sexual function 6 months after first delivery. Obstet Gynecol 2008 May; 111(5):1040-4.

5. Coletti SH, Haddad JM, Barros JPF. Avaliação funcional do assoalho pélvico. In: Amaro JL, Haddad JM, Trindade JCS, Ribeiro RM. Reabilitação do assoalho pélvico nas funções urinárias e anorretais. São Paulo (SP): Segmento Farma; 2005. p. 67-75. 6. Zanetti MRD, Castro RA, Rotta AL, Santos PD, Sartori M, Girão MJBC. Impacto of supervised physiotherapeutic pelvic floor exercises for treating female stress urinary incontinence. Sao Paulo Med J 2007 September; 125(5):265-9.

7. Örnö AK, Marsál K, Herbst A. Ultrasonographic anatomy of perineal structures during pregnancy and immediately following obstetric injury. Ultrasound Obstet Gynecol 2008 September; $32(4): 527-34$.
8. Braekken IH, Majida M, Engh ME, Bø K. Test-retest reliability of pelvic floor muscle contraction measured by 4D ultrasound. Neurourol Urodyn 2009 January; 28(1):68-73.

9. Castro RA, Arruda RM, Zanetti RD, Santos PD, Sartori MGF, Girão MJBC. Single-blind, randomized, controlled trial of pelvic floor muscle training, electrical stimulation, vaginal cones, and no active treatment in the management of stress urinary incontinence. Clinics 2008 July-August; 63(4):465-72.

10. Fitzpatrick M, O'Herlihy $C$. The effects of labour and delivery on the pelvic floor. Best Pract Res Clin Obstet Gynaecol 2001 February; 15(1):63-79.

11. Barbosa AMP, Carvalho LR, Martins AMVC, Calderon IMP, Rudge MVC. Efeito da via de parto sobre a força muscular do assoalho pélvico. Rev Bras Ginecol Obstet 2005 novembro; 27(11):677-82

12. Menta SS, Schirmer J. Relação entre a pressão muscular perineal no puerpério e o tipo de parto. Rev Bras Ginecol Obstet 2006 setembro; 28(9):523-9.

13. Oliveira $C$, Lopes MAB, Longo e Pereira LCL, Zugaib $M$. Effects of pelvic floor muscle training during pregnancy. Clinics 2007 July-August; 62(4):439-46.

14. Stephenson RG, O'Connor LJ. Fisioterapia e pacientes do sexo feminino: Avaliação e tratamento. In: Stephenson RG, O'Connor LJ. Fisioterapia aplicada à ginecologia e obstetrícia. $9^{a}$ ed. Barueri (SP): Manole; 2004.p. 65-150. 
15. Bø K, Finckenhagen HB. Vaginal palpation of pelvic floor muscle strength: inter-test reproducibility and comparison between palpation and vaginal squeeze pressure. Acta Obstet Gynecol Scand 2001 October; 80(10):883-7.

16. Hulley SB, Cummings SR. Designing clinical research. Baltimore (MD): Williams \& Wilkins; 1988.

17. Bø K, Larsen S, Kvarstein B, Hagen RH. Classification and characterization of responders to pelvic floor muscle exercise for female stress urinary incontinence. Neurourol Urodyn 1990 July; 9(4):395-7.
18. Nagib, ABL, Guirro ECO, Palauro VA, Guirro RRJ. Avaliação da sinergia da musculatura abdomino-pélvica em nulíparas com eletromiografia e biofeedback perineal. Rev Bras Ginecol Obstet 2005 abril; 27(4):210-5.

19. Higa R, Lopes MHBM, Turato ER. Significados psicoculturais da incontinência urinária feminina? Uma revisão. Rev. LatinoAm. Enfermagem [online]. 2008, 16(4):779-86. ISSN 01041169. doi: 10.1590/S0104-11692008000400020. 